Halaman : $143-146$

\title{
THE DIFFERENCES OF STUDENTS' LEARNING ACHIEVEMENT BY POSTER DISPLAYING ON ENVIRONMENT TOPIC GRADE X SMA OF MEDAN
}

\author{
Ramadhoni, F.S*., Napitupulu,M.A \\ Program Studi Pendidikan Biologi Bilingual, FMIPA, Universitas Negeri Medan, Medan \\ Jl. Willem Iskandar Psr. V Medan Estate, Medan, Indonesia, 20221 \\ ${ }^{*}$ E-mail : febrinasuci.fs@gmail.com
}

\begin{abstract}
The study aims to know the difference of learning achievement by poster displaying in the environmental topic. Type of the research was quasi experiment and was designed with pre-test and post-test. The population is the students in SMA Negeri 3 and 4 Medan academic year 2015/2016. The samples consists of two groups selected purpousively for each of school, grade X MIA 10 as poster making inclution group ( $n=40$ students) and X MIA 7 as poster non-making inclution group ( $n=40$ students). Learning method in both groups was goup discussion. In first group, used poster making inclution and poster non-making inclution for the second. Multiple choice test was the instrument for cognitive data collection and questionnaires were used for student performances. Hypothesis wass tested by $t$-test. The students learning achievement result showed that, the average score in poster making inclution group (74.92) was higher than poster non-making inclution group (67.13) with persentage difference is $38 \%$. $t_{\text {count }}$ with $t_{\text {table }}$ is $t_{\text {count }}>t_{\text {table }}(4.175>1.994)$ (with $\alpha=0.05$ and $d f=78$ ). Based on the data from research result used $t_{\text {count }}>t_{\text {table }}$ then $H_{0}$ was rejected and $H_{a}$ was accepted. It means there is difference of learning achievement between student who were treated with poster making inclution and those treated with non-poster making inclution model on Environmental topic of Grade X in SMA at Medan Academic Year 2015/2016.
\end{abstract}

Keywords: Poster Making Inclution Group, Poster Non-Making Inclution Group, Learning Achievement.

\section{INTRODUCTION}

Learning process is a dynamic activity that teachers need to constantly observe the changes that occur in student in the class. It is a two-way communication, the teaching is conducted by the teacher as the educator, while the study carried out by the learners. In the learning process, the interaction between teacher and students will be more effective when student participate actively in the learning process. Student will be able to undestand the lesson from their experience and it will enhance the outcomes. Teacher today is the facilitator so everything in the learning process is many by the action of students.

Salomon and Cowen in Jagger (2012) proved that students learn new abstracts and novel concepts in both verbal and visual form and visual media make concepts more accessible to students and enhance lateral recall of information. Pinker in Jagger (2012) reinstated that visual media can support students to retain and apply new concepts to real life situations.
Poster is considered as one of media and has become one of the most important types of scientific communication at societal meetings and scientific conferences. The power of the poster is that the communicants can directly discuss their data and interpretations one-on-one or in a small group atmosphere. The feedback generated during these discussions generally proves to be more useful than the feedback in question and answer sessions following the more traditional oral presentation/lecture. The data and data analyses are visually available in a well developed local flow in a poster. According to Denzine (1999), poster session allows participation by the audience by communicating with one another. The poster can be used to develop vital research literacy skills and this in turn serves the future professional education.

In SMA 3 \& SMA 4 Medan students were observed to have difficulties in the topic of environment. The KKM of SMA 3 \& SMA 4 Medan is 70 with about $70 \%$ student is pass and $15 \%$ 
student didn't pass. In the other side, student were not actively enggaged in the leaning process. Students were observed also have difficulties to communicating the result of the topic delivered to the teacher. And also, the topic of environment is a time-consuming activity for both teacher and students. Students did not show the ability to discuss the result among them and tended to reproduce information, consider a concern for grades and task requirements, and is characterized by minimal mental effort (Cross \& Steadman; Prosser \& Trigwell in Myka \& Rubenheimer, 2005).

There are practical activities of environment pollution (KD 3.10) where students are required to analyse the data of environment changing and its effect to life. The problem solving of the environment problem by designing the recycling process of waste products and the promoting sustainable environment in KD 4.10, are considered to be time-consuming process. Teachers might find it difficult to conduct activity where practical and analytical tasks are both effort and time demanding in the first place. Poster is considered to tack the problem of time limitation for both teacher and students.

There is an urgency of using poster to improve student's academic performance. This research was intended to explore the creativity by making poster on student's academic achievement in the topic of environment SMA 3 \& SMA 4 Medan Year 2015/2016.

The objective of research is to explore the student's learning achievement by poster making inclution and poster non-making inclution group in SMA 3 \& SMA 4 Medan.

\section{RESEARCH METHOD}

The research were conducted at SMA Negeri 3 Medan, Jl. Budi Kemasyarakatan and SMA 4 Medan Jl. Gelas Medan, North Sumatera, from February to May 2016. The population of the research are the students in SMA Negeri 3 \& SMA Negeri 4 Medan. The sample was cluster sampling chosen are X MIA 10 to SMA Negeri 3 Medan and X MIA 7 to SMA Negeri 4 Medan with total number of students is 80 .

Researcher use quasi-experiment research methodology. The explanation of research procedure are: the research conducted in State University of Medan exactly in SMA Negeri 3 and 4 Medan, then the researcher use environment topic knowledge multiple choice to examine the students knowledge and poster's questionnaire to examine the indicator of poster. The knowledge test and questionnaire must be validated first by validator for construct and content. The construct is by Mr. Dr. Hasruddin, M.Pd and content is by Mr. Drs. Puji harsowo, M.Si. After that the students of supervised poster making group and non-poster supervised group were give the knowledge multiple choice for the pre-test. And for supervised poster making group were give the way to make a poster meanwhile for non-poster supervised group were not give the way to make poster after both of them give the treatment then for the final research, the researcher give them the post-test to know the increasing of the student's cognitive aspect.

The researcher formulated 30 number of questions in environment topic multiple choice test to examine students knowledge and 4 number of items in poster's questionnaire.

The Liliefors test was used to test whether the sample is normally distributed or not. The result showed that all the data of learning achievement in both groups (supervised and nonsupervised group of students in poster-making activity) is normally distributed $(\alpha=0.05)$. The highest score the students who were supervised is 86 and the lowest is 50 . Similar trend was found for the non-supervised students, the score for both lowest and highest the students could achieve is $\mathbf{5 7}$ and 91 , respectively.

To determine the sample variance, homogenity test is used and the formula as follows:

$$
\mathrm{F}=\frac{\text { Highest varians }}{\text { Lowest varians }}=\frac{S 1^{2}}{S 2^{2}}
$$

When $F_{\text {count }} \geq F_{\text {table }}, H_{0}$ will be rejected or $\mathrm{Ha}$ will be accepted.

Where :

$\mathrm{S}_{1}{ }^{2}=$ bigger variance.

$\mathrm{S}_{2}{ }^{2}=$ smaller variance

(Sudjana, 2010)

The calculation revealed that the $F_{\text {count }}$ for pre-test is 1.4393 and the learning achievement is 
Halaman : $143-146$

1.272. The table percentile $F$ value $(\alpha=0.05)$ and df numerator and denominator 39 ( $0.05=39.39$ ), the $F_{\text {table }}$ is 1.705 (with interpolation). It can be concluded that both pre-test and learning achievement data from both samples have a uniform variance (homogenous) as the $F_{\text {table }}>$ $\mathrm{F}_{\text {count }}$.

\section{Hypothesis testing}

$t$-test is used with $\mathrm{df}=(\mathrm{n} 1+\mathrm{n} 2)-2$ with significance level $\alpha=0.05$.

$$
\begin{gathered}
\mathrm{t}=\frac{\bar{X} 1-\bar{X} 2}{s \sqrt{\frac{1}{n 1}+\frac{1}{n 2}}} \\
\mathrm{~s}^{2}=\frac{(n 1-1) s 1^{2}+(n 2-1) s 2^{2}}{n 1+n 2-2}
\end{gathered}
$$

The student's average score of the supervised students group is 74.92 and the students who were not supervised showed a lower score, which is 67.13. The $t$-test showed that the $t_{\text {count }}$ is 4.175 and the $t_{\text {table }}$ is 1.994. As the $t_{\text {count }}>$ $t_{\text {table }}$ it is indicated that $\mathrm{Ha}$ is accepted and $\mathrm{Ho}$ is rejected. There is a difference of student's learning achievement between students who were treated with poster making supervision and those who were treated with no supervision applied on Environment topic of Grade $X$ in SMA at Kota Medan Academic Year 2015/2016.

\section{RESULT}

The average scores for both supervised and nonsupervised group of students in poster-making activity are not very different (58.78 and 57.68 respectively). For the supervised group, there were only 6 (six) students considered "good" and the highest score was 80 . On the other hand, its counterpart, the non-supervised group showed less students who were considered "good" with highest score of 80 .The average scores for both supervised and non-supervised group of students in poster-making activity showed different scores (74.92 and 67.13 respectively). For the supervised group, there were 31 students considered "good" and the highest score was 91. The non-supervised group showed similar trend, it has 13 students who were considered "good" and the highest score is 86.

The questionnaires were used to examine how the indicator of content, design, picture, and the message can be observed through the poster- making acitivity. The supervised-group showed better performance. All indicators show higher percentages for the supervised group. Figure 4.3 below summarizes all the result.

The average score for the supervised group is 13.23 (83\%) and the average of score of the non-supervised group is lower, 9.67 (60.47\%).

Figure 4.3. average of indictor of poster in questionaire

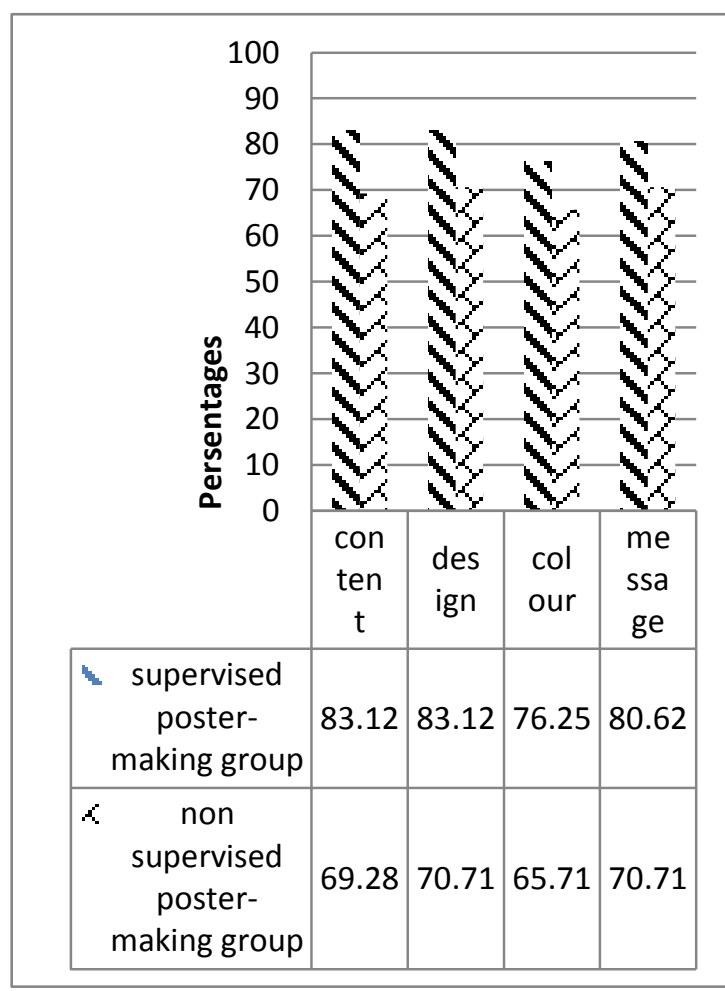

\section{DISCUSSION}

\section{Student's Cognitive Aspect}

Based on the research results, it is very clear that supervision is

Figure 4.3. the indicators of poster in the questionairesplaying its role to increase the score of students. Such improvement is expected to enhance understanding the topic of environment learning process. The result showed that the learning process is more efficient when supervision was conducted before. The students' post-test showed that the score of students is higher.

Hypothesis test result of pre-test in both groups of students showed almost similar trend (58.78 and 57.68). Both have similar cognitive ability. At the beginning the student's initial cognitive understanding is lower than it was when 
the learning process of producing poster was supervised. The initial knowledge derives from the pre-test was formally aimed to provide feedback to the teacher by measuring the initial knowledge level of the student (Greg, 2007). Students were found to focus on the guide-book provided by the school to study the topic of Environment. The book was suspected to have no contribution on providing students to have more interesting way of producing posters. Students in both school showed similar situation, that there did not reach the KKM score justified by the school and curriculum.

The post-test revealed different situation as the learning process included the supervision of how to produce poster in effective and more interesting way. Students who produced posters with supervision reached up to score of 80 , while its counterpart only reached the score of 77 .

\section{Students Poster}

There were about $83 \%$ students produced good poster in the supervised-making poster group and only $60.4 \%$ of the unsupervised group were able to produce poster which were considered good. The average score of the supervised is 78.5 and the other group is only 13.23. This big gap was expected. All indicators of observing the poster revealed that the supervised group achieve more than those who were not supervised. The more sophisticated poster will tell us about how student is developing his ability to understand the process of producing a series of facts and theory. A poster helps students to combine visual image like, line, picture, and words to attract attention and to communicate the message briefly (Anitah, 2008).

In accordance with the topic of Environment, poster may help in terms of providing more space for students to put pictures and colours which help students to work more independently and collaboratively. The topic is limited in term of content proportion in the curriculum. Students have more understandings when they include other sources and re-produce the information in the form of posters.

Teachers are playing their important role to help students to find more resources to complete the posters. Krisnawati (2014) experienced similar situation when she found out that students were more positive towards the learning process and proved to encourage students to reach their optimal achievement (92.3\%). Teachers must considered posters to be one way of delivering the concept of environment topic.

\section{CONCLUSION}

The research is again showing the importance of posters in increasing student's learning achievement. This research showed that students producing posters are more capable to produce good piece of work when the process of making posters was supervised. There are several indicators that help teachers to guide and supervise students to reach its maximal achievement.

There is a significant difference on student learning achievement and student's poster percentage between students who were supervised and who were not, when they produce posters as a way of evaluating their performance in the topic of Environment.

\section{REFERENCES}

Anitah, S ( 2008). Media Pembelajaran. Surakarta: LPP UNS dan UNS Pers.

Aziz, R.H.A.\& Jusoff, K (Corresponding author): Effective Poster Teaching Strategy towards Risk in Studying Fraud. International Eduation Studies Journal Vol.2, No. 1. www.ccsenet.org/journal.html

Denzine, G.M (1999). An example of innovative teaching: Preparing graduate students for poster presentations. Journal of College Student Development, 40(1): 91. Retrieved October 17, 2007, from ProQuest Education Journals database.

Myka, J. L. \& Raubenheimer, C. D. (2005). Action research implemented to improve Zoology laboratory activities in a freshman biology majors course Electronic Journal of Science Education, Vol. 9, No. 4, June 2005.

Sudjana, N. \& Rivai. A (2010). Media Pengajaran. Bandung: Sinar Baru Algensind 